\title{
Tetrahydrogestrinone induces a genomic signature typical of a potent anabolic steroid
}

\author{
Fernand Labrie, Van Luu-The, Ezequiel Calvo, Céline Martel, \\ Julie Cloutier, Sylvain Gauthier, Pascal Belleau, Jean Morissette, \\ Marie-Hélène Lévesque and Claude Labrie
}

Molecular Endocrinology and Oncology Laboratory, Laval University Medical Research Center (CRCHUL) and Laval University, Québec City,
G1V 4G2, Canada
(Requests for offprints should be addressed to F Labrie; Email: fernand.labrie@crchul.ulaval.ca)

\begin{abstract}
Tetrahydrogestrinone (THG) is a recently identified compound having the greatest impact in the world of sports. In order to obtain a highly accurate and sensitive assessment of the potential anabolic/androgenic activity of THG, we have used microarrays to identify its effect on the expression of practically all the 30000 genes in the mouse genome and compared it with the effect of dihydrotestosterone (DHT), the most potent natural androgen. Quite remarkably, we found that 671 of the genes modulated by THG in the mouse muscle levator ani are modulated in a similar fashion by DHT, while in the gastrocnemius muscle and prostate, 95 and 939 genes
\end{abstract}

respectively, are modulated in common by the two steroids. On the other hand, THG is more potent than DHT in binding to the androgen receptor, while, under in vivo conditions, THG possesses $20 \%$ of the potency of DHT in stimulating prostate, seminal vesicle and levator ani muscle weight in the mouse. The present microarray data provide an extremely precise and unquestionable signature of the androgenic/anabolic activity of THG, an approach which should apply to the analysis of the activity of any anabolic steroid.

Journal of Endocrinology (2005) 184, 427-433

\section{Introduction}

Identification of tetrahydrogestrinone (THG) by the US Anti-Doping Agency has created a wave of shock in the world of elite athletes, coaches and suppliers of performance-enhancing drugs (Knight 2003a), while causing great concerns at the level of the International Olympic Committee (IOC). Soon after development of the appropriate test, THG has been identified in a still growing list of Olympic medal winners and other prestigious athletes. In addition to its potential performanceenhancing properties prohibited by the IOC, there are medical safety concerns related to THG. In fact, being, like norbolethone (Catlin et al. 2002), a drug never marketed as a pharmaceutical, the in vivo biological and toxicological activities of THG are practically unknown, thus increasing the risks of its use in humans. Thus, we have taken advantage of the powerful technique of microarrays which can assess the changes of expression of practically all genes in the genome to analyze the in vivo alterations of the genomic profile in androgen-sensitive tissues of the mouse, a species where $99 \%$ of the genes have direct counterparts in the human (Waterston et al. 2002).

\section{Materials and Methods}

\section{Animals}

Eleven- to twelve-week-old male C57BL6 mice obtained from Harlan (Indianapolis, IN, USA) were allowed to acclimate for 2 weeks. The animals were housed individually in an environmentally controlled room (temperature: $22 \pm 3{ }^{\circ} \mathrm{C}$; humidity: $50 \pm 20 \%$; 12-h light-12-h darkness cycles, lights on at $0715 \mathrm{~h}$ ). The mice had free access to tap water and a certified rodent feed (Lab Diet 5002 (pellet), Ralston Purina, St. Louis, MO, USA). The experiment was conducted in an animal facility approved by the Canadian Council on Animal Care (CCAC) and the Association for Assessment and Accreditation of Laboratory Animal Care (AAALAC). The study was performed in accordance with the CCAC Guide for Care and Use of Experimental Animals and the Laval University Committee for Animal Experimentation.

\section{Treatment}

Animals weighing between $24 \cdot 0$ and $32 \cdot 4 \mathrm{~g}$ (mean= $28 \cdot 2 \pm 0 \cdot 1 \mathrm{~g})$ were randomized according to body weight 
and were assigned to 19 groups of 10 animals each. On day 1 of the study, animals were gonadectomized (GDX) under isoflurane anesthesia. All animals were killed 7 days after GDX. Mice were injected subcutaneously (s.c.) $0 \cdot 5$, $1,3,6,12$ or $24 \mathrm{~h}$ before death with dihydrotestosterone (DHT) $(0.1 \mathrm{mg} / \mathrm{mouse})$ or THG $(0.5 \mathrm{mg} / \mathrm{mouse})$. DHT and THG were suspended in 5\% ethanol-0.4\% methylcellulose. A GDX vehicle-injected group was used as a control. Eight intact mice of the same strain, age and body weight were killed as described above and tissues were collected, weighed and discarded. The mice killed 2, 4 and 7 days after starting treatment received daily injection of the steroids and were killed $24 \mathrm{~h}$ after the last injection under isoflurane anesthesia and were exsanguinated via cardiac puncture. The prostate (ventral+dorsal), seminal vesicles, preputial glands as well as gastrocnemius and levator ani muscle were collected, freed from adhering tissue or fluid and weighed.

\section{Synthesis of THG}

A mixture of gestrinone $(100 \mathrm{mg}, 0.324 \mathrm{mmol})$ and palladium on activated carbon $(10 \% \mathrm{wt})(11 \mathrm{mg})$ in dichloromethane $(50 \mathrm{ml})$ was stirred under $\mathrm{H}_{2}$ (1 atmosphere) at room temperature for approximatively $60 \mathrm{~min}$. The reaction was monitored by proton nuclear magnetic resonance $\left({ }^{1} \mathrm{H}\right.$ NMR). The mixture was filtered through a Celite pad and washed several times with dichloromethane. Solvent was removed by evaporation. The crude product was purified by flash chromatography on silica gel (hexanes-ethyl acetate/9-1 to hexanes-ethyl acetate/8-2) and by flash chromatography on reverse phase gel (C18) $\left(\mathrm{CH}_{3} \mathrm{CN}-\mathrm{MeOH}-\mathrm{H}_{2} \mathrm{O} / 10-50-50\right.$ to $\mathrm{CH}_{3} \mathrm{CN}-\mathrm{MeOH}-$ $\left.\mathrm{H}_{2} \mathrm{O} / 30-30-30\right)$ to give the desired product (THG) as a yellow foam (47 mg, 47\% yield, $98 \cdot 9 \%$ chemical purity by HPLC). ${ }^{1} \mathrm{H}$ NMR $\left(400 \mathrm{MHz}, \mathrm{CDCl}_{3}\right): \delta 0.99$ (t, $J=7 \cdot 3$ $\mathrm{Hz}, 3 \mathrm{H}), 1 \cdot 06(\mathrm{t}, J=7 \cdot 5 \mathrm{~Hz}, 3 \mathrm{H}), 1 \cdot 29(\mathrm{~m}, 1 \mathrm{H}), 1 \cdot 35-1 \cdot 95$ $(\mathrm{m}, 8 \mathrm{H}), 1.90(\mathrm{~m}, 1 \mathrm{H}), 2.08(\mathrm{~m}, 1 \mathrm{H}), 2.50(\mathrm{t}, J=7.3 \mathrm{~Hz}$, $2 \mathrm{H}), 2 \cdot 55-2 \cdot 65(\mathrm{~m}, 3 \mathrm{H}), 2 \cdot 85(\mathrm{~m}, 2 \mathrm{H}), 5 \cdot 79(\mathrm{~s}, 1 \mathrm{H}), 6 \cdot 38$ $(\mathrm{d}, J=10 \cdot 1 \mathrm{~Hz}, 1 \mathrm{H}), 6 \cdot 59(\mathrm{~d}, J=10 \cdot 1 \mathrm{~Hz}, 1 \mathrm{H}) \mathrm{ppm} .{ }^{13} \mathrm{C}$ NMR $\left(75 \mathrm{MHz}, \mathrm{CDCl}_{3}\right): \delta 7 \cdot 46,11 \cdot 35,22 \cdot 58,24 \cdot 26$, $24 \cdot 35,27 \cdot 12,30 \cdot 63,31 \cdot 51,34 \cdot 34,36 \cdot 67,37 \cdot 64,49 \cdot 02$, $50 \cdot 76,84 \cdot 13,123 \cdot 49,124 \cdot 64,126 \cdot 94,140 \cdot 84,142 \cdot 02$, $156 \cdot 58,199 \cdot 26 \mathrm{ppm}$.

\section{RNA extraction and microarray analysis}

Tissues were snap-frozen in liquid nitrogen and kept at $-80{ }^{\circ} \mathrm{C}$ prior to RNA extraction. Total RNA was isolated by Trizol (Invitrogen) and purified with Rneasy Mini Kit columns (Qiagen). The quality of total RNA, cDNA synthesis, cRNA amplification and cRNA fragmentation was monitored by micro-capillary electrophoresis (Bioanalizer 2100, Agilent Technologies, Mississauga, Ontario, Canada). Twenty micrograms of total RNA were converted to cDNA and transcribed in vitro to produce biotinylated cRNA. Fifteen micrograms

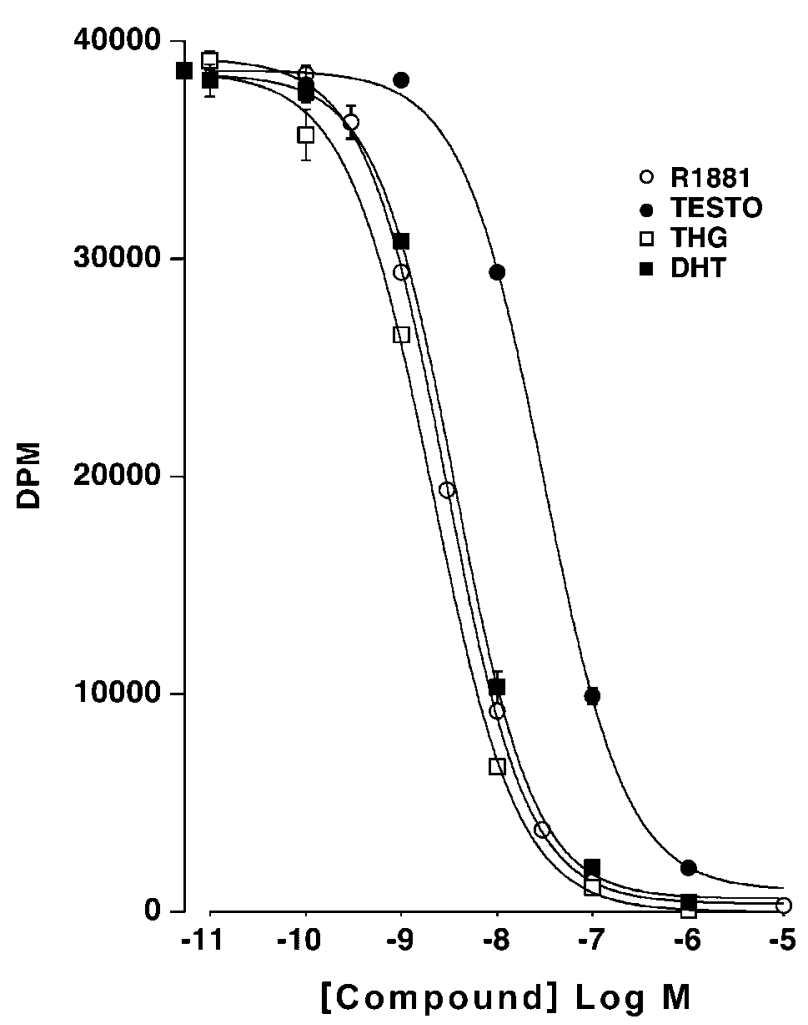

Figure 1 Effect of increasing concentrations of methyltrienolone (R1881), testosterone (TESTO), tetrahydrogestrinone (THG) and dihydrotestosterone (DHT) on [ $\left.{ }^{3} \mathrm{H}\right] \mathrm{R} 1881$ binding to the human androgen receptor. The incubation was performed with $3 \mathrm{nM}$ $\left[{ }^{3} \mathrm{H}\right] \mathrm{R} 1881$ for $16 \mathrm{~h}$ at $0-4{ }^{\circ} \mathrm{C}$ in the presence or absence of the indicated concentrations of unlabeled compounds.

fragmented cRNA were hybridized for $16 \mathrm{~h}$ at $45^{\circ} \mathrm{C}$ with constant rotation (60 r.p.m.). Microarrays were processed using the Affymetrix GeneChip Fluidic Station 400 (Affymetrix, Santa Clara, CA, USA). Staining was carried out with streptavidin-conjugated phycoerythrin (SAPE) followed by an amplification with a biotinylated anti-streptavidin antibody and by a second round of SAPE before scanning using a GeneChip Scanner 3000 (Affymetrix). The signal intensities for the $\beta$-actin and glyceraldehyde-3-phosphate dehydrogenase (GAPDH) genes were used as internal quality controls. The ratio of fluorescent intensities for the $5^{\prime}$ end and the $3^{\prime}$ end of these housekeeping genes was $<2$. Hybridization was performed in duplicate to the MOE-430 v2.0 GeneChip set (Affymetrix) according to the Affymetrix protocols. Scanned images were analyzed with Affymetrix GCOS v1.1 software and with GeneSpring 6.1 software (Silicon Genetics, Redwood City, CA, USA) as described (Vasseur et al. 2003).

\section{Androgen receptor assay}

Preparation of human embryonic kidney (HEK-293) cells stably transfected with human androgen receptor (hAR): 

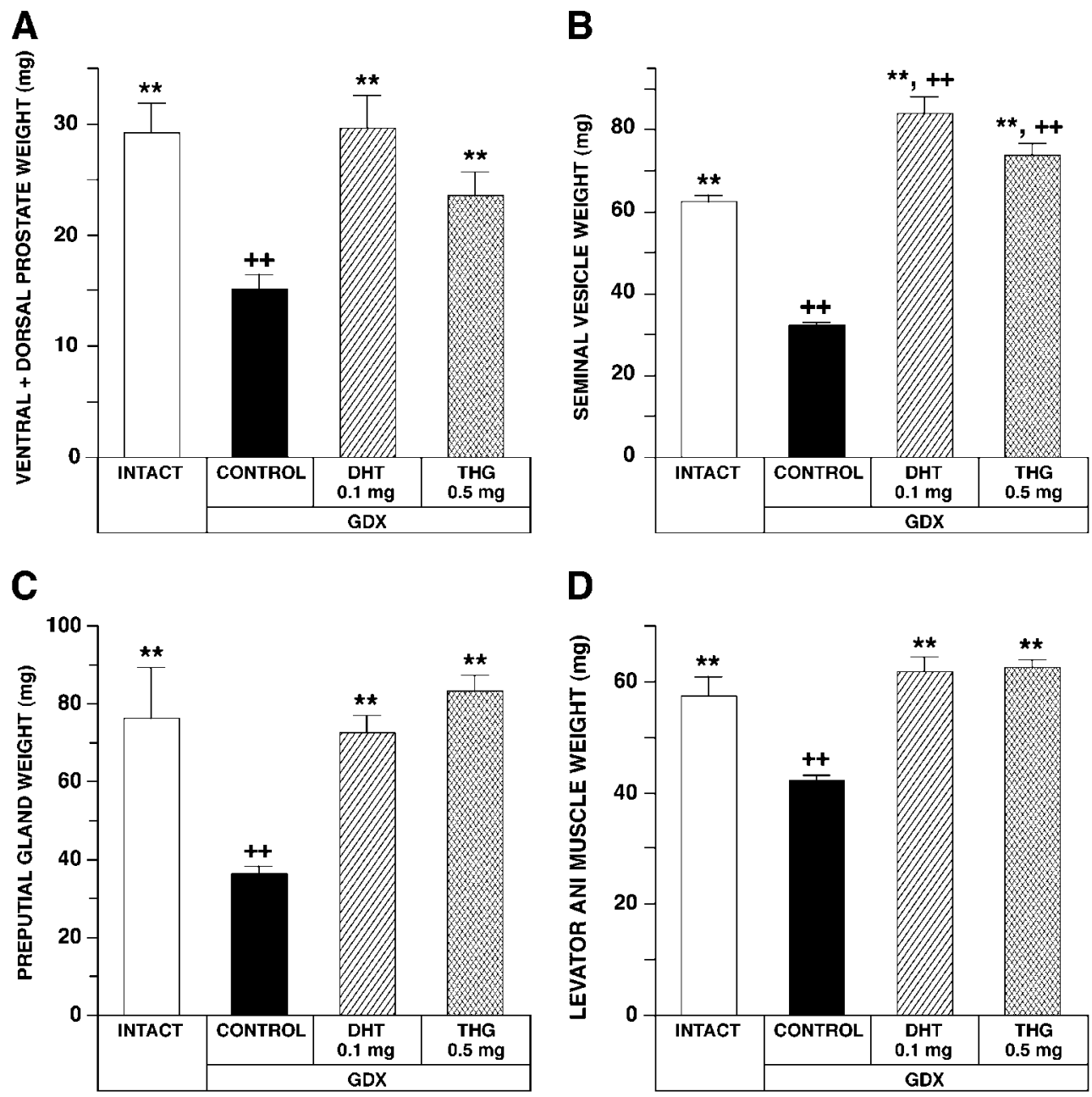

Figure 2 Effect of 7-day daily treatment with DHT or THG on the weights of (A) prostate, (B) seminal vesicle, (C) preputial gland and (D) levator ani muscle in gonadectomized (GDX) male C57BL6 mice. Data are expressed as the mean \pm S.E.M. of 10 animals per group. ${ }^{* *} P<0 \cdot 01$, experimental versus GDX-control mice, $++P<0 \cdot 01$, experimental versus intact control mice.

The pCMV neo-hAR plasmid (Huang \& Luu-The 2001) was transfected into HEK-293 cells using a lipofectin transfection kit (Life Technologies, Ontario, Canada), and cells resistant to G418 were isolated as previously described (Dufort et al. 1999). On the morning of the binding assay, a pellet of HEK-293 hAR cells was thawed, suspended in buffer, sonicated and centrifuged at $105000 \times \boldsymbol{g}$ for $90 \mathrm{~min}$. The androgen binding assay was performed with the hydroxylapatite (HAP) method (Martel et al. 1998) using HEK-293 hAR cell cytosol preparation $(0 \cdot 1 \mathrm{ml})$ and $3 \mathrm{nM}\left[{ }^{3} \mathrm{H}\right] \mathrm{R} 1881$ purchased from Perkin Elmer Life and Analytical Sciences (Ontario, Canada).

Data were expressed as means \pm S.E.M. The statistical significance was determined according to the multiple range test of Duncan-Kramer (Kramer 1956). Microarrays data were normalized with the bioconductor package, using the MAS5 and RMA normalization methods. Probe sets with an expression ratio higher (or lower) than the variable cut-off point were considered as significantly stimulated (or inhibited). A cut-off point varying with the gene expression intensity was used with the following parameters for the MAS5 method: Cop $=1 \cdot 8+97 / \mathrm{x}$ for MAS5, where Cop means the cut-off point and $\mathrm{x}$ is equal to the minimum gene expression value in the expression ratio. For the RMA method, a fixed fold change of 1.58 was considered as significant. Only probe sets considered as significantly modulated by both normalization methods at at least one time interval were kept for the clustering analysis. Probe sets were clustered hierarchically with the GeneSpring program version 6.1 (Silicon Genetics, Redwood City, CA, USA) using a Euclidian distance. 

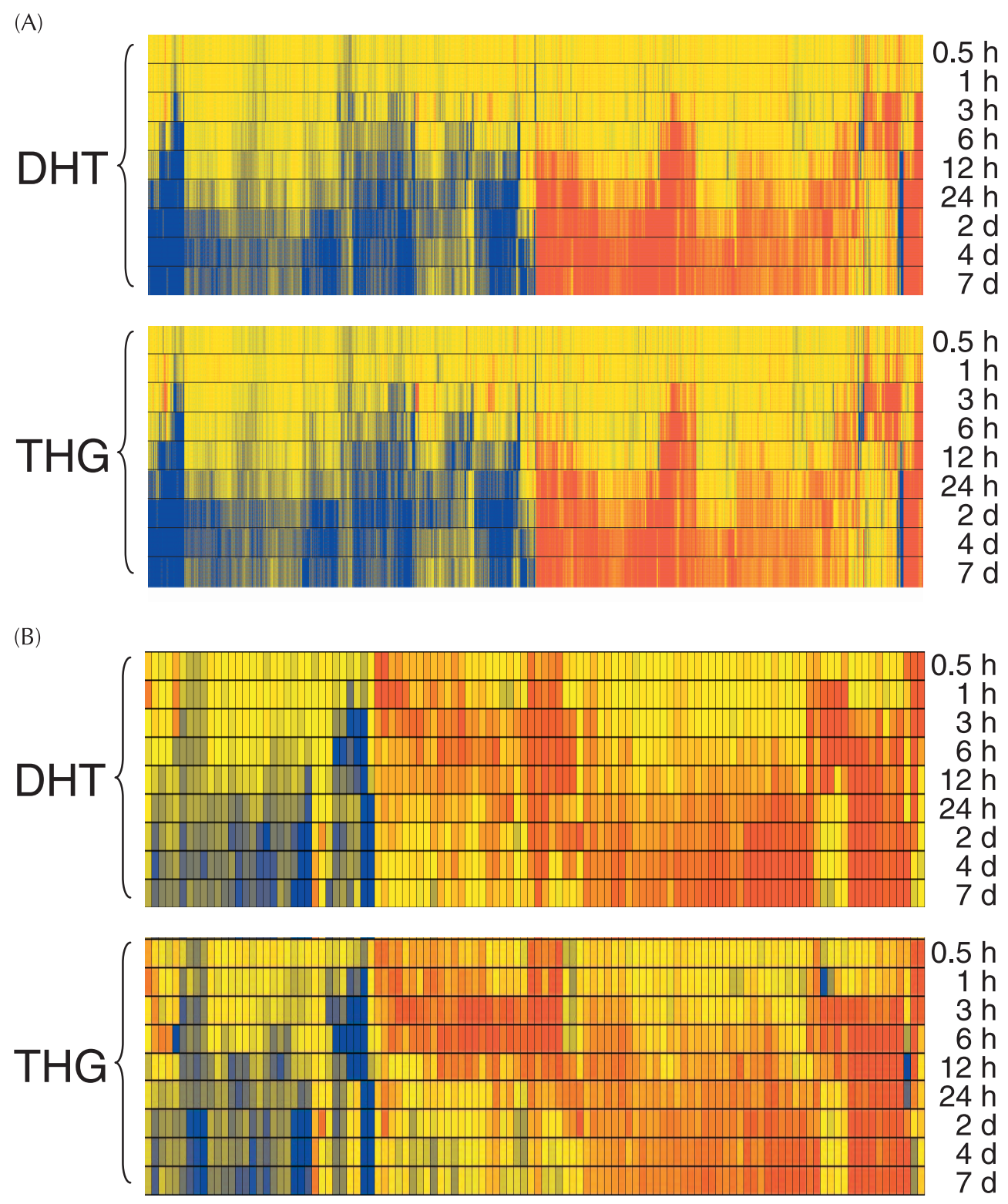

Figure $3(\mathrm{~A})$ and $(\mathrm{B})$.

\section{Results}

Since the first step in the action of androgens is binding to the androgen receptor (AR), we first compared the potency of THG with that of DHT, the most potent natural androgen, as well as with testosterone and the synthetic androgen methyltrienolone (R1881), to displace $\left[{ }^{3} \mathrm{H}\right] \mathrm{R} 1881$ from the human AR. As can be seen in Fig. 1, R1881, DHT and testosterone have relative potencies of $72 \%, 58 \%$ and $7 \%$ compared with the $100 \%$ value set for THG, the compound showing the highest affinity for AR. These data already indicate the potential high androgenic activity of THG.
We next used classical in vivo assays to assess the in vivo activity of THG. In a preliminary experiment, THG has been found to be $20 \%$ as potent as DHT as a stimulator of mouse prostate weight, the most widely used parameter of androgenic activity (Labrie et al. 1988) (data not shown). We could then select doses of the two compounds which prevent the inhibitory effect of gonadectomy on accessory sex organ weight, namely $0.1 \mathrm{mg}$ and $0.5 \mathrm{mg}$ daily subcutaneous (s.c.) doses of DHT and THG respectively. In fact, the daily injection of DHT completely reversed the GDX-induced atropy of the prostate and led to a prostate weight similar to that of intact animals (Fig. 2A). Daily treatment with $0.5 \mathrm{mg}$ THG, on the other hand, reversed 

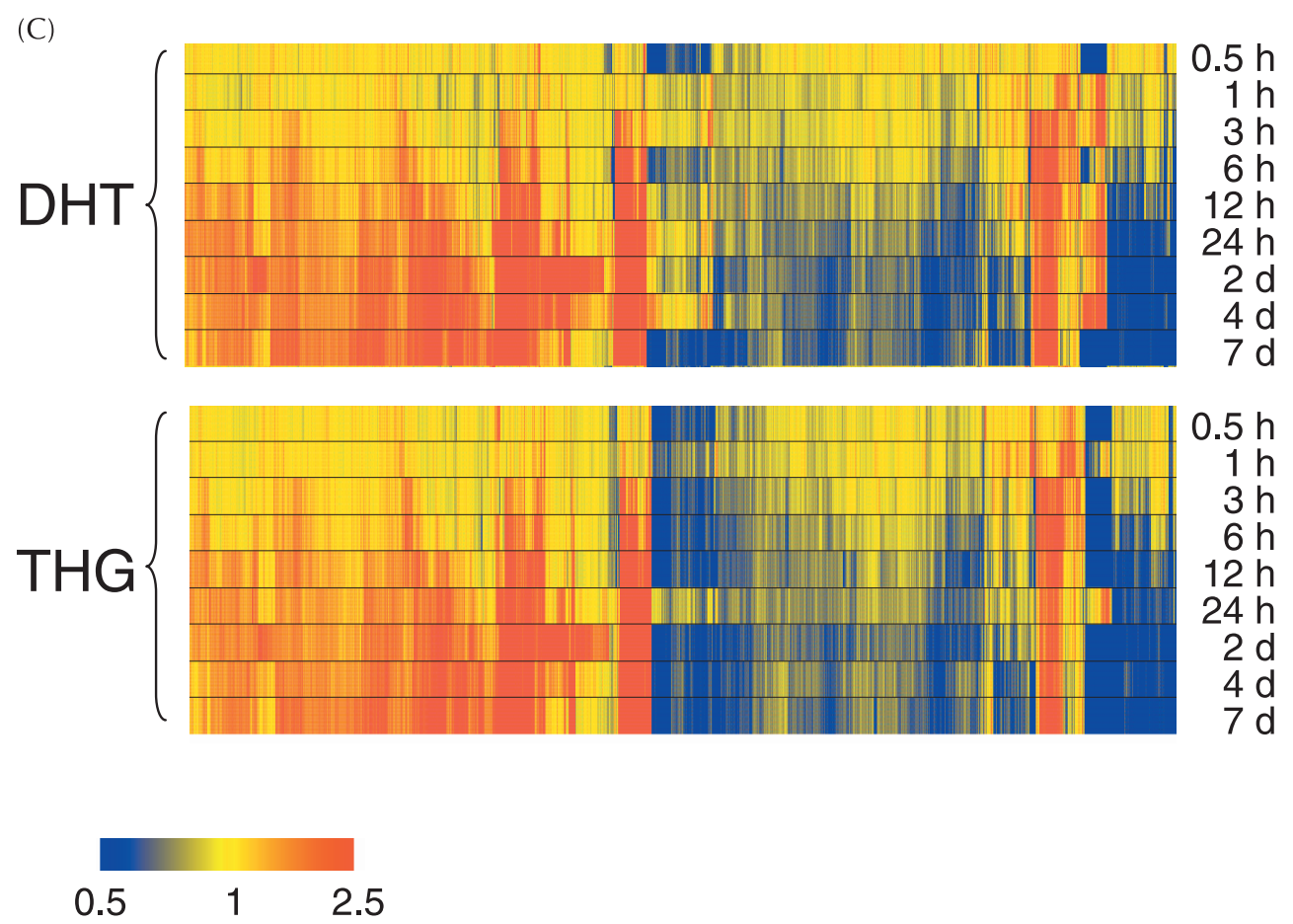

Figure $3(\mathrm{C})$.

Figure 3 Comparison of the effect of DHT on the gene expression profile by cluster analysis at $0.5,1,3,6$, 12 and $24 \mathrm{~h}$ following a single subcutaneous injection of $0.1 \mathrm{mg}$ DHT or $0.5 \mathrm{mg}$ THG or 2,4 and 7 days following daily administration of the same doses of the two steroids in the (A) levator ani muscle, (B) gastrocnemius muscle and (C) prostate of mice GDX 7 days previously. The genes selected were those identified in common according to the Affymetrix MAS 5.0 and RMA programs (Gautier et al. 2004). The color scales representing fold-changes induced by treatments are shown below the panels.

the effect of GDX to a value not statistically different from intact controls. While GDX caused $48 \%(P<0 \cdot 01)$ and $52 \%(P<0 \cdot 01)$ decreases of seminal vesicle (Fig. 2B) and preputial gland (Fig. 2C) weights respectively, the administration of DHT or THG completely reversed the GDX-induced atropy of both tissues. The levator ani is an androgen-sensitive muscle (Boissonneault et al. 1989) which has long been recognized as a myotropic marker of the androgenic/anabolic activity of steroids (Eisenberg et al. 1950). While GDX caused a $26 \%$ decrease in weight of the levator ani, the injection of DHT or THG increased the weight of the levator ani to values not different from intact animals (Fig. 2D).

The most impressive anabolic activity of THG, however, is illustrated by the very close similarity of the pattern of genes up (red)- as well as down (blue)-regulated by both DHT and THG in the androgen-sensitive muscle levator ani (Fig. 3A). In fact, the expression of 671 genes is significantly modulated in an almost superimposable fashion by both DHT and THG in the mouse levator ani. Although the gastrocnemius muscle is less androgensensitive, Fig. 3B shows that 95 genes are commonly modulated by DHT and THG in this tissue, thus resulting in another clear androgenic signature of THG. On the other hand, in the prostate, the classical androgen-sensitive tissue (Labrie et al. 1988), 939 genes are commonly modulated by DHT and THG, thus clearly providing another typical androgenic/anabolic signature of the action of THG (Fig. 3C). Not only are a large number of genes similarly up- or down-regulated in the three tissues by the two steroids but also their time course of action is almost superimposable (Fig. 3). In fact, the majority of changes in the gene expression pattern are seen within the first $24 \mathrm{~h}$, while almost identical pictures are observed at days 2, 4 and 7 since the changes seen on day 2 usually remain on a plateau up to day 7. It is worth noting that not only the time course but also the amplitude of the effects induced by DHT and THG are very close.

It could be seen that the majority of genes/transcripts modulated by the two steroids are in the categories (according to Gene Ontology, www.geneontology.org) of binding, catalytic activity, signal transduction activity, transcriptor activity, transcription regulatory activity and structural molecule activity. Among the genes that are modulated by both DHT and THG in the three tissues studied, it is worth noting the presence of Fos, a gene 
involved in multiple signaling pathways, dual specific phosphatase 1 (DUSP1), and pyruvate dehydrogenase kinase 4 (PDK4), a gene involved in glucose metabolism. MyoD, a marker of muscle differentiation, is also stimulated in the levator ani by both THG and DHT. Among the genes/transcripts found to be modulated by both DHT and THG in the prostate, it is of interest to mention that 69 of these have already been shown to be modulated by DHT in this tissue following quantitative real-time PCR measurement (Q_RTPCR).

Among the modulated transcripts already validated by Q_RTPCR, CAI is a calcium binding protein related to a protein disulfide isomerase, and MAN1A is a mannose oxidase involved in the maturation of Asn-linked oligosaccharides. This enzyme progressively trims alpha-1, 2-linked mannose residues from Man(9)GlcNAc(2) to produce Man(5)GlcNAc(2). NUCB2 is a calcium-binding protein that belongs to the nucleobindin family. FKBP5 is a drug (FK506)-binding protein possessing peptidyl-prolyl cis-trans isomerase activity which interacts with functionally mature hetero-oligomeric progesterone receptor complexes along with HSP90 and telomerase binding protein p23 (TEBP). SERPINE 2 is a heparin binding protein involved in the regulation of proteolysis and peptidolysis, while arginase 2 (ARG2) is a manganese ion binding protein and metalloendopeptidase (MME) is a zinc binding protein involved in proteolysis and peptidolysis. NCOA4 (ARA70) is a coactivator that interacts with the androgen receptor and RXR, while NKX3-1 is a transcription factor involved in nucleotide and nucleic acid metabolism. RSG2 is a signal transducer of a G-protein coupled with cAMP nucleotide second messenger, while CCL9 is a protein possessing chemokine activity by binding to a G-coupled chemokine receptor. HP (haptoglobin) is a hemoglobin binding protein possessing the signature of a serine protease that has lost all essential catalytic residues and has no enzymatic activity. NANS is an antifreeze-like protein that could bind ice and is involved in the production of $\mathrm{N}$-acetylneuraminic acid (Neu5Ac) and 2-keto-3-deoxy-D-glycero-D-galactonononic acid (KDN). MTHFD2 is a bifunctional enzyme containing methylenetetrahydrofolate dehydrogenase and cyclohydrolase activities. This enzyme is involved in folate as well as glyoxylate and dicarboxylate metabolism. On the other hand, $3^{\prime}$-phosphoadenosine $5^{\prime}$-phosphosulfate synthase 2 (PAPSS2) is a bifunctional enzyme with both ATP sulfurylase and APS kinase activities involved in the biosynthesis of $3^{\prime}$-phosphoadenosylphospho sulfate (PAPS) that acts as sulfate donor cofactor for sulfotransferases. BPGM is a biphosphoglycerate phosphatase controlling 2,3-BPG concentration that plays a major role in regulating hemoglobin oxygen affinity, while IDI1, isopentenyl-diphosphate delta isomerase, is an enzyme of the isoprenoid biosynthetic pathway whose end products include dolichols, vitamins $\mathrm{A}, \mathrm{D}, \mathrm{E}$ and $\mathrm{K}$, steroid hormones, carotenoids, bile acids and cholesterol.

\section{Discussion}

The power of gene-expression profiling has been clearly demonstrated in clinical medicine by the capability to divide adult acute myeloid leukemia into subgroups having different responses to specific treatments (Bullinger et al. 2004, Valk et al. 2004), thus permitting the choice of the best treatment for each category of cancer while avoiding the serious side effects of inefficient treatments and the vital time lost trying inappropriate therapy while the cancer continues to progress (Burnett 2002, Mistry et al. 2003).

THG is the largest drug scandal in the history of world sport (Kondro 2003). The first drug tests by the IOC were run at the 1968 Olympic Games in Mexico where only ethanol was found, while the first detection of banned drugs was made in six athletes in Munich in 1972. The chemical synthesis of THG was designed to escape detection since the compound degrades during standard gas chromatography and mass spectrometry procedures (Kondro 2003). THG was identified in the laboratory of Donald Catlin at UCLA in June 2003 from a sample sent in a syringe to the US Anti-Doping Agency (Knight 2003b).

THG is clearly not a dietary supplement. The present data show that this steroid has $20 \%$ the potency of DHT, the most potent natural androgen. Similarly, dehydroepiandrosterone (DHEA) and androstenedione are not dietary supplements since these two steroids are transformed in the tissues which possess the appropriate enzymatic machinery into the same highly potent androgen DHT (Labrie 1991, Labrie et al. 1998, 2003). THG differs from gestrinone by reduction of the ethynyl to an ethyl group at position $17 \alpha$. Such a change can translate into unknown differences of biological activity and toxicity. Gestrinone is a compound which possesses androgenic, as well as antiprogestin and some estrogenic activities (AzadianBoulanger et al. 1973, Sakiz et al. 1974, Raynaud et al. 1975). Gestrinone is used in clinical medicine on a small scale, especially for the treatment of endometriosis (Dawood et al. 1997), uterine myoma (De Leo et al. 2002) and mastalgia (Peters 1992). The side effects observed with gestrinone include hirsutism, acne, voice changes, weight gain and increased hemoglobin (Coutinho et al. 1986, Coutinho 1989). It is expected that THG will also decrease gonadotropin secretion by the anterior pituitary gland as observed in our animal studies with the parent compound gestrinone (Kelly et al. 1979), thus leading to inhibition of testicular and ovarian activity in men and women taking THG. Our data also suggest an interaction between androgen action and oxygen consumption as indicated by the activation by DHT and THG of bisphosphoglycerate mutase, which regulates hemoglobin oxygen affinity.

In conclusion, the changes in the genomic profile induced in androgen-sensitive tissues, including muscles, 
provide an extremely precise and unquestionable signature of the androgenic/anabolic activity of THG used by athletes to artificially increase their performance. In addition to its potent androgenic/anabolic and progestin (Death et al. 2004) activities, the toxicity profile of THG is completely unknown, thus making this compound an unknown risk for human use.

\section{Acknowledgements}

This study was supported by Genome Canada and Genome Québec. We thank Dr Christiane Ayotte, Director, Doping Control Laboratory, INRS for very helpful discussions. The authors declare that there is no conflict of interest that would prejudice the impartiality of this scientific work.

\section{References}

Azadian-Boulanger G, Secchi J \& Sakiz E 1973 Biological study of the antiprogesterone effect of R2323. Proceedings of the VIIth World Congress on Fertility and Sterility, Amsterdam, p 129. Eds T Hasegawa, FJG Ebling \& IW Henderson. Amsterdam: Excerpta Medica.

Boissonneault G, Gagnon J, Ho-Kim MA, Rogers PA \& Tremblay RR 1989 Depressed translational activity in the androgen sensitive levator ani muscle of the rat. Journal of Steroid Biochemistry 32 507-513.

Bullinger L, Dohner K, Bair E, Frohling S, Schlenk RF, Tibshirani R, Dohner H \& Pollack JR 2004 Use of gene-expression profiling to identify prognostic subclasses in adult acute myeloid leukemia. New England Journal of Medicine 350 1605-1616.

Burnett AK 2002 Current controversies: which patients with acute myeloid leukaemia should receive a bone marrow transplantation? An adult treater's view. British Journal of Haematology 118 357-364.

Catlin DH, Ahrens BD \& Kucherova Y 2002 Detection of norbolethone, an anabolic steroid never marketed, in athletes' urine. Rapid Communications in Mass Spectrometry 16 1273-1275.

Coutinho EM 1989 Gestrinone in the treatment of myomas. Acta Obstetricia et Gynecologica Scandinavica Supplement 150 39-46.

Coutinho EM, Boulanger GA \& Goncalves MT 1986 Regression of uterine leiomyomas after treatment with gestrinone, an antiestrogen, antiprogesterone. American Journal of Obstetrics and Gynecology 155 761-767.

Dawood MY, Obasiolu CW, Ramos J \& Khan-Dawood FS 1997 Clinical, endocrine, and metabolic effects of two doses of gestrinone in treatment of pelvic endometriosis. American Journal of Obstetrics and Gynecology 176 387-394.

De Leo V, Morgante C, La Marca A, Musacchio MC, Sorace M, Cavicchioli C \& Petraglia F 2002 A benefit-risk assessment of medical treatment for uterine leiomyomas. Drug Safety 25 759-779.

Death AK, McGrath KC, Kazlauskas R \& Handelsman DJ 2004 Tetrahydrogestrinone is a potent androgen and progestin. Journal of Clinical Endocrinology and Metabolism 89 2498-2500.

Dufort I, Rheault P, Huang XF, Soucy P \& Luu-The V 1999 Characteristics of a highly labile human type 517 beta-hydroxysteroid dehydrogenase. Endocrinology 140 568-574.

Eisenberg S, Buie R Jr \& Tobian L Jr 1950 Adrenal cortical function in essential hypertension; a study of sweat sodium concentration. American Journal of Medical Sciences 220 287-289.
Gautier L, Cope L, Bolstad BM \& Irizarry RA 2004 affy-analysis of Affymetrix GeneChip data at the probe level. Bioinformatics 20 307-315.

Huang X-F \& Luu-The V 2001 Modulation of the androgenic response by recombinant human 11-cis retinol dehydrogenase. Journal of Steroid Biochemistry 77 129-133.

Kelly PA, Asselin J \& Labrie F 1979 Endocrine regulation of growth and hormone receptor levels in DMBA-induced mammary tumors. In Steroids Receptors and the Management of Cancer, pp 3-29. Eds EB Thompson \& ME Lippman. Boca Raton, Florida: CRC Press Inc.

Knight J 2003a Drugs bust reveals athletes' secret steroid. Nature $\mathbf{4 2 5}$ 752.

Knight J 2003b Drugs in sport: no dope. Nature 426 114-115.

Kondro W 2003 Athletes' 'designer steroid' leads to widening scandal. Lancet 3621466.

Kramer CY 1956 Extension of multiple range tests to group means with unique numbers of replications. Biometrics 12 307-310.

Labrie C, Bélanger A \& Labrie F 1988 Androgenic activity of dehydroepiandrosterone and androstenedione in the rat ventral prostate. Endocrinology 123 1412-1417.

Labrie F 1991 Intracrinology. Molecular and Cellular Endocrinology 78 C113-C118.

Labrie F, Bélanger A, Luu-The V, Labrie C, Simard J, Cusan L, Gomez JL \& Candas B 1998 DHEA and the intracrine formation of androgens and estrogens in peripheral target tissues: its role during aging. Steroids 63 322-328.

Labrie F, Luu-The V, Labrie C, Bélanger A, Simard J, Lin S-X \& Pelletier G 2003 Endocrine and intracrine sources of androgens in women: inhibition of breast cancer and other roles of androgens and their precursor dehydroepiandrosterone. Endocrine Reviews $\mathbf{2 4}$ 152-182.

Martel C, Provencher L, Li X, St-Pierre A, Leblanc G, Gauthier S, Mérand Y \& Labrie F 1998 Binding characteristics of novel nonsteroidal antiestrogens to the rat uterine estrogen receptors. Journal of Steroid Biochemistry and Molecular Biology 64 199-205.

Mistry AR, Pedersen EW, Solomon E \& Grimwade D 2003 The molecular pathogenesis of acute promyelocytic leukaemia: implications for the clinical management of the disease. Blood Reviews 17 71-97.

Peters F 1992 Multicentre study of gestrinone in cyclical breast pain. Lancet 339 205-208.

Raynaud JP, Bonne C, Bouton MM, Moguilewsky M, Philibert D \& Azadian-Boulanger G 1975 Screening for anti-hormones by receptor studies. Journal of Steroid Biochemistry 6 615-622.

Sakiz E, Azadian-Boulanger G \& Raynaud JP 1974 Antiestrogens antiprogesterone. Proceedings of the IVth International Congress of Endocrinology, Amsterdam, p 998. Eds FJG Ebling \& IW Henderson. Amsterdam: Excerpta Medica.

Valk PJ, Verhaak RG, Beijen MA, Erpelinck CA, Barjesteh van Waalwijk van Doorn-Khosrovani S, Boer JM, Beverloo HB, Moorhouse MJ, van der Spek PJ, Lowenberg B et al. 2004 Prognostically useful gene-expression profiles in acute myeloid leukemia. New England Journal of Medicine 350 1617-1628.

Vasseur S, Malicet C, Calvo EL, Labrie C, Berthezene P, Dagorn JC \& Iovanna JL 2003 Gene expression profiling by DNA microarray analysis in mouse embryonic fibroblasts transformed by rasV12 mutated protein and the E1A oncogene. Molecular Cancer Therapeutics 219.

Waterston RH, Lindblad-Toh K, Birney E, Rogers J, Abril JF, Agarwal P, Agarwala R, Ainscough R, Alexandersson M, An P et al. 2002 Initial sequencing and comparative analysis of the mouse genome. Nature 420 520-562.

Received 16 September 2004 Accepted 19 November 2004 